\title{
소액신용(Microfinance) 고위급 회의
}

소액신용에의 접근 확대를 위한 고위급 회의가 프 랑스에서 6월 20일(월) 개최되어 빈곤층에 대한 금융 서비스 확대를 위한 정부, 민간 금융기관, $\mathrm{NGO}$ 의 역 할 모색을 주제로 하여 총 4개 Session이 진행된 바, 주요 내용은 다음과 같음.

\section{I . 핵심요지}

동ㅇ 회의에 참가한 정부기관, 비정부기구(NGO) 및 민간금융기관 관계자들은 소액신용이 빈곤 퇴치 에 대한 만병통치약(Panacea)은 아니나 유용한 수 단임을 인정하며, 천년개발목표(MDGs)를 위하여 동 수단이 확대, 발전되어야 함을 촉구하였음.

Chirac 대통령은 이 소액신용의 확대 및 발전을 위한 국제적 목표 수립 필요성을 향후 G8 및 UN 정상회담에서 주도적으로 제기할 것이라고 밝혔 으며 특히 아프리카와의 연대 없이는 프랑스와 유
럽의 미래를 상상할 수 없다면서 아프리카와의 파 트너십 및 對아프리카 개발전략에 있어서의 소액 신용의 중요성을 강조하였음.

\section{II. 관찰 및 평가}

동 회의는 빈곤문제 해결을 위한 수단으로 소액신 용의 확대 필요성을 강조한 Chirac 대통령의 의지 를 반영하기 위해 개최된 것으로 프랑스는 금번 회 의 결과를 향후 $\mathrm{G} 8$ 정상회담 및 $\mathrm{UN}$ 의 $\mathrm{MDG}+5$ 검토회의 등에서 계속 제기해 나갈 것으로 보임. - 특히 금번 회의에는 불어권 아프리카 국가 대표 단들이 대거 참가한 점이 주목됨.

ㅁ또한 소액신용의 확대 및 발전을 위한 정부기관의 역할 모색과 민간 금융기관과의 연계 문제에 대해 MFIs(소액신용기 관: Micro Finance Institutions), $\mathrm{NGO}$ 와 민간금융기관 간의 활발한 논쟁(이자율 
등)이 진행되었으나, 금번 회의는 구체적인 결론 도출보다는 상호 입장파악 및 정보를 공유하는 차 원에서 진행되었음. 제도 구축 등 구체적인 내용은 이후 독일에서 개최될 소액신용회의(6월 22 일 23일)에서 논의될 것으로 관찰됨.

Mr. Jacques Attali(현 Planet Finance(NGO) 대 표, 전 유럽부흥개발은행 총재)은 프랑스가 현재 $\mathrm{ODA}$ 의 약 $3 \%$ 를 소액신용분야에 할애하고 있으 나 동 비중을 $6 \%$ 로 증대하는 것을 중기적 목표로 추진할 필요가 있다고 제안한 바, 동 제의는 향후 $\mathrm{ODA}$ 의 사업구성에 큰 영향을 미칠 것으로 보임. 금번 회의를 계기로 소액신용이 ODA의 주요한 사 업분야로 부각될 가능성이 있으므로 향후 우리의 $\mathrm{ODA}$ 계획 수립에 참고할 필요가 있다고 봄.

\section{III. 주요내용}

\section{1. 개막식(Opening)}

Chirac 대통령의 임석하에 프랑스 개발청장(Jean

Michel Severino)의 소개로 방글라데시 Yunus (그라민은행 총재)를 포함하여 볼리비아, 모로코, 세네갈 고위급 인사들이 자국의 성공적인 소액신 용 현황을 설명하고 소액신용의 확대 및 관련 제도 의 정비를 촉구함.

\section{Chirac 대통령은 연설을 통해}

- 소액신용은 빈곤퇴치를 위해 중요한 역할을 할 것이며 $\mathrm{MDG}$ 달성을 위해 확대되어야 함을 강 조하였으며
- 관련법과 제도의 정비, Private Sector와의 파 트너십 구축의 필요성을 언급하였고

- G8회담과 UN정상회담에서 프랑스가 소액신용 확대 논의를 주도할 것을 천명하였음.

- 특히 對아프리카 개발에 있어서의 소액신용의 중요성을 지적하며 ⿶ㅝㅇ아프리카 원조 확대 및 5 개 분야(안보, 보건, 교육, 인프라, 무역분야)의 파트너십 강화를 강조하며 향후 G8 회담에서 이를 제기하겠다고 밝힘.

\section{Session 1 : 소액신용의 수요에 대한 이해와 평가}

Microsave 등 3개 MFI 대표 패널들은 소액신용 대 상자 폭의 확대 및 대상자의 필요(Needs)를 고려한 소액신용상품의 다양화가 필요하다는 의견을 제시 - Vulnerable Non-Poor로의 대상자 확대, 농촌 지역(Rural Area)의 수요 파악의 필요성

- Lifecycle을 고려한 다양한 소액신용상품(교육, 건강 등) 개발

- NGO, MFI의 능력 향상의 필요성 촉구

\section{Session 2: 정부 및 중앙은행의 역할 모색}

동ㅇ 세션에서는 정부가 시장을 왜곡하지 않고 소액 신용을 활성화(소액신용의 효율성 증대, 민간기관 과의 연계, 제도화)하는 방법에 대해 논의하였음.

- 정부의 개입을 근본적으로 반대하는 의견부터 정부개입의 필요성을 주장하는 의견(건전한 금 융환경 구축, 금융정보의 제공, 법과 제도의 정 비, 모니터링 시스템 도입, 정부의 보증 등)까지 다양한 의견이 제시됨. 


\section{Session 3: 민간 부문과 시민사회와의 새로운 관계 모색}

ㅁ동 세션에서는 $\mathrm{NGO}, \mathrm{MFI}$ 와 민간 금융기관의 연 계에 대한 논의가 이루어졌으며 민간 금융기관은 소액신용의 성공적 운영사례를 소개하고, 소액신 용이 하나의 금융상품 및 새로운 투자로서 공식 민 간금융기관과 연계, 확대되는 관점을 제시함.

- 특히 Ms. Maria Nowak(Association for the Right to Economic Initiative and European Microfinance Network 대표) 및 Mr. Kimanthi Mutua(K-REP Bank, Kenya)는 소액신용이 과 거와 달리 그 규모가 커지고 새로운 시장으로 변 형되어 가고 있다고 하면서 동 부문이 공식 금융 권에 들어오게 될 것이라고 지적

ㅁㄸㄸ한 민간금융기관과 $\mathrm{MFI}$ 간의 성공적인 파트너 십을 위한 방안(보조금, Regulatory institution의 필요성 등)이 논의됨.

\section{Session 4 : 촉매자로서 Donors의 역할}

ㅁ동 세션에서는 정부기관 및 민간 금융기관 등 Donors의 역할 변화를 논의함.

- 가난한 사람들에게 돈을 빌려주는 역할에서 가 난한 사람들을 위한 금융제도를 활성화하고 효 율적으로 운영하도록 촉진하는 역할(Catalyst) 로의 전환

- 소액신용의 재원 확보에 거래비용을 줄일 수 있 도록 MFI에 대한 Rating(평가), 전문성 확보, 지역 금융시장의 발전을 통한 자금 유통 강화 등 을 언급 $\square$ Mr. Jacques Attali(Planet Finance)는 Planet Finance의 활동을 소개하고 보다 효율적인 소액신 용을 위해 MFIs에 대한 Rating System 개발 필요 성, IT기술의 소액신용에의 적용 등을 제안하였음. 므프랑스 외무성의 Mr. Philippe Etienne 국제협력 국 총국장은 아직 소액신용 분야에 많은 경험이 축 적되지 않았음을 언급하며 공공부문의 역할로 소 액신용의 발전을 위한 지원방법 고안, 공식 금융기 관과의 연계 구축 및 재원 확보 증진 등을 제시하 며 프랑스 개발청의 사례(소액신용의 Risk 관리 등)를 설명함.

[자료:주프랑스 대사관] 